\title{
Brief Discussion on Seniors Care Mode of Medical-Seniors Care Integration in the View of Healthy Aging
}

\author{
Lin Yang, Xinhong Qi, Wei Liu, Yue Wang, Long Ge, Hua Yao* \\ The First Affiliated Hospital of Xinjiang Medical University, Urumqi, China \\ Email: ${ }^{* 1804878185 @ q q . c o m ~}$
}

How to cite this paper: Yang, L., Qi, X.H., Liu, W., Wang, Y., Ge, L. and Yao, H. (2017) Brief Discussion on Seniors Care Mode of Medical-Seniors Care Integration in the View of Healthy Aging. Open Journal of Social Sciences, 5, 37-44.

https://doi.org/10.4236/jss.2017.56005

Received: April 13, 2017

Accepted: June 6, 2017

Published: June 9, 2017

\begin{abstract}
The trend of aging population in our country is gradually obvious at present, The nation is getting old before getting rich, the medical care and seniors care resources of seniors are separated, which bring great challenge to the seniors of accessing to quality medical care and seniors care resources, healthy aging goal couldn't be guaranteed, the sick seniors are usually suffering from chronic diseases with long period illness, complications, treatment difficulty and long-time care, the economic burden of disease and cost of health care workers increased rapidly, with the increase of seniors population that couldn't take care of themselves, the demand for medical services and long-term care would present a trend of rapid growth, the existing pattern of family care, medical services and financing structure of medical care will be under huge challenge. The traditional concepts of "keeping our aging population healthy and out of poverty" is under tremendous impact, the research on the integration of medical-seniors care is of great practical significance to demands of the large amount of disabled and semi-disabled who need to be taken care of, is the only way to enter the healthy aging in China.
\end{abstract}

\section{Keywords}

Healthy Aging, Integration of Medical-Seniors Care, Demand, Guarantee

\section{Introduction}

Aging is an inevitable phase of human progress, along with the incoming of grey wave, the trend of aging population in China has come into view [1], contradictions between growing needs of medical care for seniors and shortage of current medical care resources are increasingly intensified, Handling the supporting problem of seniors has constituted a new challenge to the economic and social 
development in China. According to the statistics data of National Bureau, the total population of China in 2015 has exceeded 1.36 billion [2], seniors population over 60 years old is 210 million, which account for $15.5 \%$ of the total population; population over 65 years old is 137 million, which account for $10.1 \%$ of the total population. The problems of daily care and seniors care for the seniors are prominent, and the aging population with associated health problems brings severe challenges to the current medical and elder-care system. How to take care of the medical and care needs of this part seniors raises new requirements to the construction of medical health and seniors care service systems, the medical and seniors care resources are separated at present, the costs of medical care and retirement continue to rise, the problem of difficulty in expensive medical treatment has become an urgent livelihood problem to be solved in the aging population society [3], Therefore, how to integrate the medical and seniors care resources, overall plan the layout from the national level and diversify management are the priorities to our healthy aging, "keeping our aging population healthy and out of poverty", improvement on happiness index of the seniors and construction of harmonious society.

\section{The Definition of Integration of Medical-Seniors Care}

Integration of Medical-Seniors Care refers to the combination of medical resources and seniors care resources to maximize the utilization of social resources. Among them, "medical" refers to medical rehabilitation care services, including services of medical, health counseling, health inspection, disease diagnosis and treatment, serious illness rehabilitation and Hospice care; "support" includes life care services, mental and psychological services, cultural activities [4]. With the development mode of medical-seniors care, integrating medical care, rehabilitation, health maintenance and supporting, putting the health demand of seniors in the first place, combining the supporting and medical care to realize the new pattern of supporting service with the life and rehabilitation care as a whole.

\section{Service Needs from Healthy Aging to "Integration of Medical-Seniors Care"}

The definition of health in 1946 constitution of the World Health Organization is: "Health is the perfect state of physical, psychological and social function", that is, to inspection the function of physical organs and measure all the indicators to see if they are normal, whether Psychological spirit could adapt the changes of outside world and check the social adaptability from the sociological point of view. According to the statistics of Ministry of Health: The prevalence rate of chronic diseases for seniors over 60 years old is 3.2 times of total population in China, the medical expenses consumed by seniors is 1.9 times of cost of average consumption of health resources for the entire population. Chronic disease is given priority to the treatment of hospital, which causes high charge against revenue and financial pressure on medical insurance. The service object 
for "Integration of Medical-Seniors Care" is not only referring to seniors that couldn't take care of them and need long-term professional medical services, but should be all seniors [5]. The service timing for "Integration of Medical-Seniors Care" not only refers to provide health care services at the time of seniors disabled or semi-disabled, but intervene early and strengthen the prevention of chronic diseases, especially for the diseases that has large impact on daily life of seniors, Taking effective way to reduce the risk of diseases is far more meaningful than treating diseases, which could save medical resources and lower the medical cost.

\section{Current Development Situation of Seniors Care Service Industry}

\subsection{Current Situation Abroad}

Due to the differences of social and economic development, the developed countries took the lead in the aging society, The medical security level and living infrastructure in the developed countries was relatively complete, life expectancy of the seniors was higher, and the developed countries had generous welfare with low birth rate, which was forced to enter the aging society early, the mode of integration of medical-seniors care in developed countries is much mature and diverse that could better meet the needs of healthy aged-care. In accordance with their own national conditions, the developed countries developed various modes of integration of medical-seniors care to deal with population aging and created long-term care system.

The United States formed relatively mature aged-care modes in the process of population aging [6], which mainly with types of life self-care, life assistance, special care and community aged-care, supporting agencies get seniors care staff on duty of 24 hours and provide professional care services, help the seniors to complete daily activities of eating, changing and bathing, supply social and recreational activities to achieve "seniors care-LOHAS-Hospice", Japan is one of the most serious aging countries in the world, its aged-care mode mostly reply on family and relatives supporting, supplemented by public welfare and socialized services. Major feature is with complete laws and regulations, which cleared the service objects, stipulated the responsibility of nation and local government, pointed out the direction for seniors care service. Aged-care service of Australia has developed a strict admittance and retreating system for staff of supporting agencies, the government set up a special seniors Health Ministry to oversee service quality of agencies, establish assessment group for seniors care, and conduct medical care, seniors care and psychology for the seniors with comprehensive assessment, and then determine the type of medical care needed for the seniors accordingly, medical institutions sent out for regular health care for the seniors and guide medical services of safe seniors care, rational drug use.

In short, the governments of developed countries provide institutional guarantee for the development of seniors care service in the establishment and improvement of legal system, while fully mobilize and take advantage of private 
capital, enterprises and other social resources to invest in market of seniors care, and promote the development of non-profit organizations, thus form a sustainable medical care-seniors care service system. The effective operation of seniors care service system has fully played greatest advantage of market self-regulation and government macro-control.

\subsection{Current Situation in Domestic}

After entering into aging society in 1999, China accelerated the construction of seniors-care service system and the improvement of relevant policies and regulations, proposed "Extended Seniors Care at Home (EACH)" in 2006, the State issued Opinions on comprehensively promoting the work of home care service in 2008, proposed gradually establishing and improving seniors care system of home care based, community care supported and institutional care supplemented. The traditional mode of seniors care is $\mathrm{EACH}$, the function of home care has been weakening at present, the problems of treatment and caring for seniors bother thousands of households, and more seniors tend to choose institutional care agencies. The current situation is that the medical institutions and seniors care agencies are independent and self-contained. Seniors care homes are not convenient for medical treatment while the hospitals couldn't afford services for the aged, the seniors had to split their time at home, hospitals and seniors care agencies which takes time and energy. The recovery of chronic diseases for seniors takes longer, many sick seniors treat the hospitals as seniors care home just in case, the situation of occupying beds is severe which makes difficult to find beds in large hospitals, those critical patients with real need on hospital couldn't live in there. The medical-seniors care integration in Proposals on Accelerating the Development of seniors care Industry Services from State Council in 2013 will be a new idea on solving the challenges of aging population, The State issued Guidance on Promoting the Integration of Medical Healthcare and seniors care Service in November, 2015, proposed that the integration of medical healthcare and seniors care service is a long term policy and positive response to aging population [7], which is conducive to meet the needs of growing diverse medical care and seniors care from the masses, is essential measure to solve the practical difficulties of increasingly inadequate of medical recourses and pension funds.

\section{The Existing Problems in the Development of Medical-Seniors Care Integration at Present Stage}

\subsection{The Influence of Traditional Culture}

The pursuit of "Family happiness" from seniors made them reluctant to go to seniors care institutions, while due to the limit conditions of home care, most sick seniors couldn't get timely treatment and basic medical needs can't be guaranteed, The reasons of long term impact of family planning policy, changes of modern family functions, population mobility, heavy work of children, short- 
age of care resources and empty-nest family make the traditional EACH more difficult, "Family Happiness" is the need of the seniors [8], but new contents should be poured into new seniors care and adjusted to keep pace with times so as to improve the life quality of seniors and extend the length of their healthy life.

\subsection{Implement and Supervision of Medical-Seniors Care Integration Not in Place}

At present, the preferential policy given on construction land of seniors care home, equipment purchase, operating subsidies and medical security in China is not clear, the implementation situation is poor, the problem of medical expenses of seniors caused at seniors care agencies couldn't enjoy medical insurance reimbursement has not been properly solved. The access and exit mechanism of medical-seniors care integration institutions is unclear and the service quality is lack of supervision and scientific evaluation, the public seniors care institutions should play the function of "build up a basic safety net, ensure there is a cushion in place for those most in need" and focus on providing medical and care service for seniors with "No Parents, No Child, No Partner", seniors with low income and disabled or semi-disabled seniors with economic difficulties, while the reality is that charge of medical-seniors care institutions is high and the income of seniors is low [9], so the public institutions are welfare of small number of seniors with good economic conditions, part of private seniors care institutions are free from government supervision.

\subsection{Low Level of Medical Service, Narrow Scope of Service Object}

At present, the problems of single service object and low service level exist in most seniors care institutions with mode of medical-seniors care integration in China, and the existing phenomenon of separation of medical institutions, segmentation of medical management, decentralization of medical resources and insurance lead to the low utilization rate of medical health resources and severe waste of medical resources [10], thus there're no more resources and ability to better take care of seniors, only part of seniors with disability and dementia could be looked after, added with the low service quality and level, the growing health needs of seniors couldn't be satisfied.

\subsection{Large Number Gap and Low Quality of Professional Talents}

Shortage of professional medical care personnel for seniors is another important factor that restrict the development of "Medical-Seniors Care Integration" service, due to unclear position of medical care staff in seniors care institutions, low salary level, Imperfect planning of career development, low social recognition, high strength of seniors care work, large pressure of mental health, which lead to weak sense of career belonging and stability, low sense of social achievement, severe shortage of professional talents and high rate of staff turnover [11], thus growing blowout needs of health care for seniors couldn't be satisfied. 


\section{Suggestions on Promoting and Improving the Mode of Medical-Seniors Care Integration}

\subsection{Improve the Top Design, Strengthen Policy Support}

Promotion on the development of medical-seniors care integration mode must be supported by the national policy, to formulate scientific and specific development planning of medical-seniors care integration mode, perfect the corresponding land, manning quotas, equipment purchase, drug management and expenditure guarantee, clear the government position, establish, overall plan and coordinate administrative institutions of medical-seniors care integration work In accordance with the law and rules, establish and improve the standard of seniors care industry; Perfect the medical insurance system, expand the scope of medical insurance coverage; strict the entry and exit standard of medical-seniors care integration institutions; actively guide the commercial insurance to carry out measures of healthy endowment insurance business and create positive policy environment and social atmosphere for medical-seniors care integration mode, unify the recognition and responsibility to ensure healthy and orderly development of medical-seniors care integration industry under the requirements of healthy aging.

\subsection{Strengthen Financial Support, Guarantee Fund Supply}

The seniors population base in China is large, the development of medical- seniors care integration mode requires large amount of funds from state, and there's a big gap of economic development level between China and the developed countries, the phenomenon of nation get old before get rich is common and prominent; the capital markets are not perfect and fund gap of pension insurance is bigger, so improvement on corresponding preferential tax policies is needed so as to relief charges of water, electricity, gas, heat and so on, improve support policy of subsidy and establish scientific and strict evaluation mechanism of seniors care service as soon as possible, increase subsidies for seniors with economic difficulties, provide more public services for seniors and accelerate the rapid development of medical-seniors care integration.

\subsection{Follow the Market Rules, Strengthen the Macro Adjustment}

The extensive development of medical-seniors care integration couldn't be carried out without the participation of social forces, and actively explore the government, profit organizations, non-profit organizations to participate in health care services, expand raising channels of pension funds, overall plan the integration of various resources, develop the seniors care service industry with multi-level and all-dimension to actuate the wheels of government and social action at the same time, complement advantages of public and private, form the medical-seniors care integration service mode with reasonable structure and mutual promotion, continue to meet the growing, afforded and adapted needs of medical-seniors care integration from seniors under different economic condi- tions, 
so as to ease the seniors care crisis brought by large number of seniors population under Healthy aging requirements, enhance the happiness index for the seniors and guarantee social stability.

\subsection{Train professionals Professional Talents, Improve Service Level}

Train professionals a large number of high-quality professional talents, improve the overall quality of human resources services, on one hand, to strengthen training for operations management personnel of medical-seniors care integration to improve its improve its operational management level, strengthen regularly special training for existing seniors care staff of pension institutions to enhance its seniors care ability and service level. On the other hand, to encourage higher education institutions in medical to set up majors of seniors care, standardize the settings of professional curriculum, accelerate scale reserves of cultivation on gerontology talents, speed up cultivating the medical talents on aspects of gerontology, rehabilitation, seniors care, psychology, develop preferential measures and actively college students to take part in the work of medical seniors care integration after their graduation, establish and improve qualification attestation, title Assessment, career planning and reasonable salary level of practitioner staff, lay a solid talent base for medical seniors care integration service.

\subsection{Actively Develop Basic Industries of Healthy Seniors Care Services}

Healthy aged-care service industry is a new industry with great potential development at a certain stage of social progress and fundamental industry that could ease the situation at the progress of aging population, it should be developed vigorously, and first of all, it's healthy development is inseparable from the related Laws and regulations and policy support, to create a good development environment for seniors care industry, secondly, to increase financial support and tax relief to give strong backing to seniors care service industry, In the end, to promote the related industries by market competition.

The article analyses the advantages and disadvantages of medical-seniors care integration service mode in the perspective of healthy aging at present stage in China, states the connotation of seniors care mode with medical-seniors care integration, this model gives full play to the major advantages of medical and seniors care institutions, at present, seniors care institutions with medical seniors care integration Is still in the development stage of transition and exploration, influenced by the manpower, material and financial resources, society and government policy, In view of the large population of seniors and severe shortage of seniors care resources in our country, we should establish various forms to meet the seniors care needs from seniors with different economic conditions based on the healthy aging demand, stick to government dominated, market regulated and national conditions based, build the seniors care industry with medical seniors care integration in an all-round way, provide quality, efficient and sus- 
tainable and secure seniors care services for the majority of the seniors group.

\section{Fund Project}

Xinjiang Uygur Autonomous Region Social Science Fund Project 2016BGL106.

\section{References}

[1] Fei, M. (2012) Grey Wave-Current Analysis of Population Aging in China, 12nd, September 2012. http://blog.sina.com.cn/s/blog 555a226401018jm7.html

[2] 2014 Annual National Economic Statistics from National Bureau of Statistics. (2015)

[3] Huang, J.H. and Meng, F. (2014) Necessity, Difficulty and Strategy of Seniors Care Mode with Medical Seniors Care Integration. Chinese Academy of Health Policy, 7, 6.

[4] Wang, L.H., Duan, L.S., Liu, Y., et al. (2016) Practice on the Pathway of the "Combination of Pension and Healthcare" in Tertiary General Hospital. China Hospital, 20, 32-34.

[5] Zhao, X.F. (2014) Research on Seniors Care Mode of "Medical-Seniors Care Integration" under Healthy Aging. Lanzhou Academic Journal, 9,129-136.

[6] Matus-Lopez, M. and Pedraza, C.C. (2015) Building Long-Term Care Policies in Latin America: New Programs in Chile. Journal of the America Medical Directors Association, 16, 900-904. https://doi.org/10.1016/j.jamda.2015.07.018

[7] Qu, H.Q. (2015) Research on Mode of "Medical Seniors Care Integration" Institution under the Socialist Economic System. Research on Financial and Economic Issues, 6,3 .

[8] Li, X.M., Feng, Z.Y., Wang, X., et al. (2016) Problems in the Implementation of Medical-Seniors Care Models in Some Second-Class Hospitals and Its Countermeasure Analysis. Chinese Health Service Management, 1, 16-18.

[9] Huang, J.H. (2013) The Investigation and Reflection on the Pension Demand of Empty Nest Seniors in the Urban Area-Taking Hefei as an Example. Theoretical Exploration, 3,101-104.

[10] Yang, Z.Z. (2014) Construction and Empirical Study on Financing Mode of Social Pension Service with Medical Seniors Care Integration. Zhejiang University, Zhejiang, 65-66.

[11] Pan, Y.H., Liu, D., Cao, H., et al. (2012) SWOT Analysis on the Implementation of Family Physician System in Shanghai. Chinese General Practice, 15, 1146-1148. 
Submit or recommend next manuscript to SCIRP and we will provide best service for you:

Accepting pre-submission inquiries through Email, Facebook, LinkedIn, Twitter, etc. A wide selection of journals (inclusive of 9 subjects, more than 200 journals)

Providing 24-hour high-quality service

User-friendly online submission system

Fair and swift peer-review system

Efficient typesetting and proofreading procedure

Display of the result of downloads and visits, as well as the number of cited articles Maximum dissemination of your research work

Submit your manuscript at: http://papersubmission.scirp.org/

Or contact jss@scirp.org 